\title{
Melanin-based plumage ornamentation signals condition and physiological stress in the Black-headed Gull
}

\author{
Piotr Minias ${ }^{1}$ (1) Piotr Indykiewicz ${ }^{2} \cdot$ Jacek J. Nowakowski ${ }^{3} \cdot$ Mateusz Ledwoń $^{4} \cdot$ Jarosław Kowalski $^{5} \cdot$ Jacek Betleja $^{6}$. \\ Beata Dulisz ${ }^{3} \cdot$ Amelia Chyb $^{7} \cdot$ Tomasz Janiszewski $^{1}$
}

Received: 11 January 2019 / Revised: 17 June 2019 / Accepted: 15 July 2019 / Published online: 26 July 2019

(c) The Author(s) 2019

\begin{abstract}
There is increasing evidence that melanin-based plumage ornaments play a role in the sexual selection of birds, although there seems to be little consensus on the mechanisms underlying the signalling function of melanin-based plumage. The aim of this study was to assess the potential of a melanin-based plumage ornament (brown hood) to reflect components of individual quality (condition and physiological stress) in a common larid species, the Black-headed Gull Chroicocephalus ridibundus. For this purpose, we measured the size of the hood in over 500 Black-headed Gulls captured in several breeding colonies distributed across Poland. We found that hood size correlated positively with blood haemoglobin concentration, although we found no evidence for a relationship with blood glucose concentration or body mass. There was also a negative relationship between hood size and physiological stress, as assessed by leucocyte profiles (heterophil/lymphocyte ratio). We found this correlation in both sexes, suggesting that hood size may be an honest signal of individual quality in males and females, which implies a mutual mate choice in the Black-headed Gull. Finally, the relationship between hood size and blood haemoglobin concentration was primarily attributed to the parallel variation of these traits among the colonies, suggesting that Black-headed Gulls may settle in colonies in a despotic manner. As far as we are aware, our study is one of the first to show an honest signalling role of melanin-based ornaments in the gull family, Laridae. It remains to be tested whether different melanin-based plumage ornaments in gulls are developmentally and functionally integrated with each other and with carotenoid-based integument coloration.
\end{abstract}

Keywords Chroicocephalus ridibundus · Blood haemoglobin concentration · Ecophysiology · Leucocyte profiles · Melanin-based ornament $\cdot$ Sexual selection

Communicated by L. Fusani.

Electronic supplementary material The online version of this article (https://doi.org/10.1007/s10336-019-01690-7) contains supplementary material, which is available to authorized users.

Piotr Minias

pminias@op.pl

1 Department of Biodiversity Studies and Bioeducation, Faculty of Biology and Environmental Protection, University of Łódź, Banacha 1/3, 90-237 Łódź, Poland

2 Department of Biology and Animal Environment, Faculty of Animal Breeding and Biology, UTP University of Science and Technology, Mazowiecka 28, 85-084 Bydgoszcz, Poland

3 Department of Ecology and Environmental Protection, Faculty of Biology and Biotechnology, University of Warmia and Mazury in Olsztyn, Plac Lodzki 3, 10-727 Olsztyn, Poland

4 Institute of Systematics and Evolution of Animals, Polish Academy of Sciences, Sławkowska 17, 31-016 Kraków, Poland

5 Sierpc, Poland

6 Department of Natural History, Upper Silesian Museum, Plac Jana III Sobieskiego 2, 41-902 Bytom, Poland

7 Faculty of Biology and Environmental Protection, University of Łódź, Banacha 1/3, 90-237 Łódź, Poland 


\section{Zusammenfassung}

\section{Durch Melanin bedingte Farbmuster im Gefieder signalisieren bei Lachmöwen (Chroicocephalus ridibundus) den Gesundheitszustand sowie physiologischen Stress.}

Es gibt immer mehr Hinweise auf die Rolle, die Melanin-bedingte Muster in der Gefiederfärbung bei der Partnerwahl von Vögeln spielen, wobei allerdings nur wenig Übereinstimmung darüber herrscht, welches die Mechanismen sein könnten, die der Signalwirkung der Gefiederfärbung zugrunde liegen. Das Ziel dieser Untersuchung war es festzustellen, wie groß das Potential der Melanin-bedingten Farbmuster (braune Häubchen) als Informationsquelle zur individuellen QualitätGesundheitszustand und möglicher physiologischer Stress—von Lachmöwen (Chroicocephalus ridibundus) ist. Hierfür ermittelten wir die Größe des Häubchens bei mehr als 500 Lachmöwen, die wir in mehreren Brutkolonien quer durch ganz Polen gefangen hatten. Wir fanden eine positive Korrelation von Häubchengröße mit der Hämoglobinkonzentration, jedoch keine Hinweise auf einen Zusammenhang auch mit Blutzuckerkonzentration und Körpermasse. Ferner gab es eine negative Korrelation zwischen Häubchengröße und physiologischem Stress, den wir über das Leukozytenprofil (Verhältnis von Heterophilen zu Lymphozyten) bestimmten. Diesen Zusammenhang fanden wir für beide Geschlechter, woraus geschlossen werden könnte, dass das Häubchen ein wirklich zuverlässiges Signal für die individuelle Qualität von Weibchen und Männchen und damit bei Lachmöwen ein gegenseitiges Partnerwahl-Kriterium sein könnte. Der Zusammenhang zwischen Häubchengröße und Hämoglobinkonzentration im Blut war in erster Linie der parallelen Variabilität dieses Merkmals zwischen den Kolonien zuzuschreiben, was nahelegt, dass die Lachmöwen möglicherweise willkürlich und gezielt in einer bestimmten Kolonie brüten. Soweit wir wissen, ist unsere Untersuchung die erste, die für Möwen eine echte Signal-Funktion der Melanin-bedingten Gefiedermuster nachweist. Es bleibt nachzuprüfen, ob unterschiedliche Melanin-bedingte Farbmuster im Gefieder der Möwen entwicklungsbiologisch und funktionell miteinander und mit der durch Karotinoide beeinflussten Gefiederfarbe verbunden sind.

\section{Introduction}

There is increasing interest in the role of melanin-based plumage ornaments in the behavioural ecology and sexual selection of birds. Most pioneering work on the colourful ornaments of birds focused almost exclusively on carotenoids. As carotenoids cannot be synthesized de novo by an organism, carotenoid-based pigmentation is determined by the availability of carotenoids in the diet. Carotenoids also play an important role as antioxidants, which generates a serious trade-off between their allocation to plumage expression and an organism's fight against free radicals [the oxidation handicap hypothesis (Alonso-Alvarez et al. 2008)]. This is important with regards to hypotheses on the reliability of carotenoid-based signals, as individuals of high genetic and phenotypic quality should have the capacity to secure more carotenoid-rich food (e.g. through a better ability to forage or higher dominance rank) and, consequently, should have brighter and larger carotenoid-based ornaments (Hill 1991; Hill et al. 2002). It has also been reported that the expression of carotenoid ornaments depends on the current physical state or health of an individual, which is consistent with condition-dependent expression (Johnsen et al. 2003; Saks et al. 2003) and the viability indicator hypothesis, which assumes that only individuals in superior condition are able to maintain the high expression of secondary sexual traits (Andersson 1994; Svobodová et al. 2018).

The mechanisms responsible for the condition-dependent expression of melanin-based ornaments are likely to differ significantly from those for carotenoid pigments, as melanin is easily synthesized in melanocytes and is under tighter genetic control (Ducrest et al. 2008). However, there is still much debate on how exactly melanin-based ornaments can signal individual quality in an honest way. A hypothesis on the general cost of melanin synthesis has received little empirical support and experimental manipulations of some coarse metrics of an individual's condition (i.e. food intake, disease state) failed to detect a significant condition-dependence of melanin ornament expression (reviewed in McGraw 2008). Consequently, far more subtle mechanisms have been suggested to be in operation. First, the expression of melanin-based ornamentation may be limited by the availability of certain chemical elements or organic compounds, such as metals or amino acids. For example, the size and coloration of a melanin-based ornament (black breast stripe) in Great Tits Parus major correlated positively with environmental and feather concentrations of certain trace metals (Dauwe and Eens 2008; Giraudeau et al. 2015). It has also been experimentally demonstrated that a calcium-enriched diet increased the number of black breast feathers grown in the Zebra Finch Taeniopygia guttata, resulting in a larger black plumage patch (McGraw 2007). Similar effects have been observed through manipulating the dietary intake of amino acids that are crucial for melanin synthesis, e.g. restricting phenylalanine and tyrosine reduced the intensity (eumelanin content) of the black bib patch in the House Sparrow Passer domesticus (Poston et al. 2005). Second, it has been suggested that in some avian lineages (especially those with androgen-dependent development of male plumage) expression of melanin-based pigmentation is regulated by testosterone concentrations (Bókony et al. 2008), which 
may occur at the cost of immunosuppression (Buchanan et al. 2003). Finally, the costs of melanin-based coloration may be associated with its correct distribution and arrangement in the integument, as coordinating the expression of a given gene in multiple cells can be costly (Ferns and Hinsley 2004).

Although no single mechanism may reliably explain melanin-based ornaments across all taxa and all environmental or social contexts, it seems absolutely crucial to determine how general the honesty of melanin-based signals is in animals. Although several authors have used a meta-analysis approach to test this hypothesis in birds, they have reached contradictory conclusions, likely due to the low statistical power of these analyses resulting from the scarcity of taxon-specific empirical studies (Griffith et al. 2006; McGraw 2008; Guindre-Parker and Love 2014). For example, the most recent meta-analysis by Guindre-Parker and Love (2014) was based on data collected from only 21 species, most of which were from a single order of Passeriformes. Thus, if the fundamental question on melanin-based ornamentation is to be answered soon, more empirical data must be collected under a broad phylogenetic framework.

The aim of this study was to assess the potential of a melanin-based plumage ornament to reflect components of individual quality in a common larid species, the Black-headed Gull. Based on human perception, Black-headed Gulls are monochromatic and their plumage is dominated by whitish and greyish coloration, except for the black wingtip and brown hood. Our study focused on the latter, which is much more exposed than the wingtip and, thus, can be more easily assessed by potential mates. Also, the brown hood solely develops for the reproductive season and disappears in the eclipse plumage, which strongly suggests it has a role in mate choice. Our earlier work provided support for assortative mating of Black-headed Gulls with respect to hood size (Indykiewicz et al. 2017). At the same time, no assortative mating with respect to hood coloration (brightness and chroma) was found and between-individual variation in hood reflectance was negligible, which suggests that a possible signal of condition would be more efficiently conveyed by the size of the hood rather than its coloration (Indykiewicz et al. 2017). Here, we aimed to expand on these results and test for correlations of hood size with condition and physiological stress in male and female Black-headed Gulls. For this purpose, we used data from over 500 Black-headed Gulls captured in several breeding colonies distributed across Poland.

\section{Methods}

\section{General field procedures}

Black-headed Gulls were captured in 2018 across 16 breeding colonies in Poland (Fig. 1). Colony size varied between
100 and 3000 individuals. All birds were captured between 25 April and 15 June 2018 during egg incubation and chick-rearing. Birds were caught in nest traps and mist nets placed directly above nests with eggs or chicks. Trapping procedures caused no brood losses. For each captured bird we recorded the hour of capture (between 7.30 a.m. and 7.30 p.m.). In total, we captured 544 gulls (15-69 individuals per colony). Birds were individually ringed to avoid recaptures and all individuals were captured only once during the study. We collected a set of basic morphological measurements from each bird, including wing length $( \pm 1 \mathrm{~mm})$ and total head length $( \pm 0.1 \mathrm{~mm})$. Sex of birds was determined based on total head length, which is a highly dimorphic trait in the Black-headed Gull (Allainé and Lebreton 1990; Palomares et al. 1997), and allowed us to correctly sex $>90 \%$ of birds in our study population [based on the discriminant function developed for nearly 400 molecularly sexed individuals breeding in Poland (Indykiewicz et al. 2019a)]. In our dataset, 234 and 309 individuals were classified as males and females, respectively. For each bird we collected ca. $10 \mu \mathrm{l}$ of blood from the ulnar vein in order to assess condition (haemoglobin and glucose concentrations) and physiological stress (leucocyte profiles). We also measured time interval between bird capture (the moment of capture in the net) and blood sampling (henceforth referred to as 'sampling time').

\section{Hood size measurements}

Hood size was measured with an elastic metric tape as the distance from the base of the bill (feather-maxilla border) to the posterior border of the hood along the mid-sagittal plane of the head (Fig. 2). The measurements were made directly on live individuals in the field with an accuracy of $1 \mathrm{~mm}$. Our measurement showed high within-individual repeatability $(R=0.87,95 \% \mathrm{CI}=0.76-0.93, P<0.001)$, as assessed for 35 randomly selected individuals (two independent measurements per individual conducted by the same person during a single capture event). Accurate measurements of the total hood area (using digital photographs) were not possible because of the loose skin on the neck directly below the bill. Because of this loose skin, small changes in the position of the bill and neck resulted in huge changes in the total hood area and within-individual repeatability of these measurements was unsatisfactory $(R=0.49,95 \%$ $\mathrm{CI}=-0.089-0.799, P=0.059$; as assessed using two independent photographs taken for 20 individuals during a single capture event). For the same reason, we could not accurately measure the distance from the hood to the ventral (breast) side. In contrast, skin on the top and back of the head is attached to the skull (Stettenheim 2000), which allows for far more repeatable measurements that are less dependent on a bird's position. Visual assessment of hoods in all captured 
Fig. 1 Distribution of sampled Black-headed Gull colonies in Poland

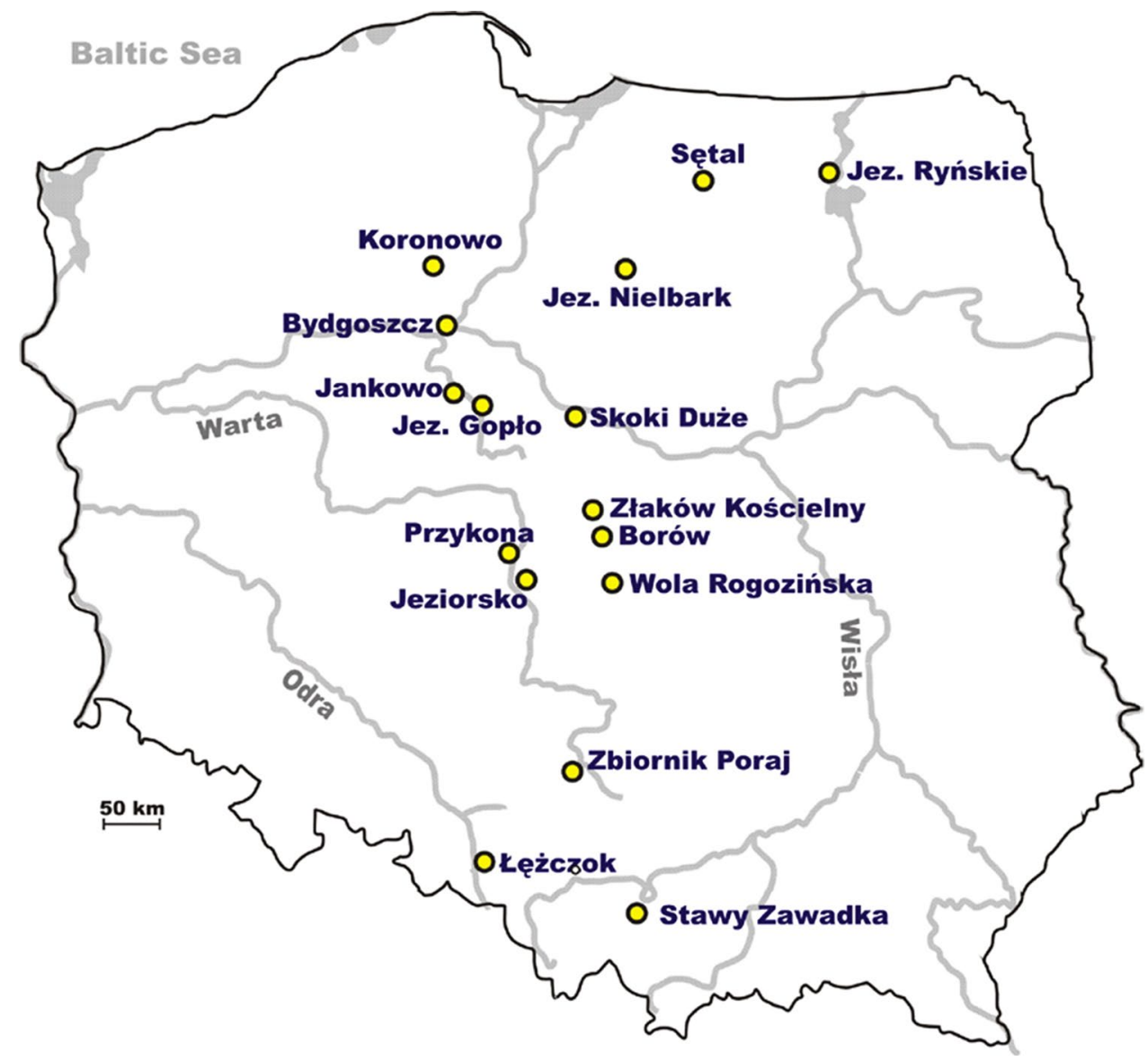

gulls also provided a clear indication that the range of hood size on the dorsal side (back of the head) showed greatest between-individual variation (while other hood dimensions were much less variable) and was likely to determine most variation in the perceived total hood size (P. M., personal observation).

\section{Condition indices}

We used three different condition indices: body mass, blood haemoglobin concentration, and blood glucose concentration. Body mass was measured with an electronic balance $( \pm 1 \mathrm{~g})$ in all but two individuals upon capture ( $n=542$; Table 1). Blood concentrations of haemoglobin and glucose were measured with HemoCue 201+ portable photometers (HemoCue, Ängeholm, Sweden). For this purpose, ca. $5 \mu$ l of blood was collected from the ulnar vein of each bird into disposable HemoCue microcuvettes (one microcuvette per measurement). The absorbance, directly proportional to the concentration of haemoglobin/glucose was measured within $1 \mathrm{~min}$ of blood sampling. Both haemoglobin and glucose concentrations have commonly been used as condition indices in wild birds. Haemoglobin concentration is a general measure of blood oxygen-carrying capacity in vertebrates, which has
Fig. 2 Variation in the size of the melanin-based hood in the Blackheaded Gull. Yellow line indicates the line of hood size measurement (colour figure online) 
Table 1 Summary statistics for hood size, condition indices and heterophil:lymphocyte $(H / L)$ ratio in male and female Blackheaded Gulls

\begin{tabular}{|c|c|c|c|c|c|c|c|c|}
\hline \multirow[t]{2}{*}{ Trait } & \multicolumn{4}{|c|}{ Females } & \multicolumn{4}{|l|}{ Males } \\
\hline & Mean & SE & Range & $n$ & Mean & SE & Range & $n$ \\
\hline Hood size $(\mathrm{cm})$ & 70.76 & 0.43 & $56-93$ & 309 & 73.05 & 0.48 & $58-92$ & 234 \\
\hline Body mass (g) & 232.52 & 1.23 & $185-305$ & 307 & 265.46 & 1.31 & $202-320$ & 234 \\
\hline Blood haemoglobin concentration $(\mathrm{g} / \mathrm{l})$ & 171.52 & 1.02 & $98-214$ & 298 & 171.13 & 1.19 & $108-230$ & 229 \\
\hline Blood glucose concentration (g/dl) & 214.63 & 3.04 & $87-377$ & 276 & 216.25 & 3.54 & $52-298$ & 213 \\
\hline $\mathrm{H} / \mathrm{L}$ ratio & 1.16 & 0.07 & $0.10-4.65$ & 124 & 1.10 & 0.07 & $0.09-3.85$ & 110 \\
\hline
\end{tabular}

been shown to correlate with a wide spectrum of fitnessrelated traits in birds, including the timing of breeding, survival, and development stability (reviewed in Minias 2015). Blood haemoglobin was also experimentally demonstrated to reflect diet quality in passerines (Pryke et al. 2011; Pryke and Rollins 2012). Thus, haemoglobin concentration was recommended as a robust indicator of physiological condition in birds (Minias 2015). In contrast, blood glucose concentration was recently suggested to be an inverse indicator of condition. Although blood glucose concentration primarily reflects metabolic rate of an organism (Brown 1996), glucose levels in circulating blood may increase due to the mobilization of organismal body reserves under high energy expenditure, stress or poor feeding conditions (Remage-Healey and Romero 2001; Corbel et al. 2010). While this mobilization of glucose may be physiologically important in certain situations (e.g. during a stress response), there is accumulating evidence that blood glucose levels can negatively correlate with other aspects of condition in wild birds. For example, blood glucose concentrations in passerine nestlings have been reported to negatively correlate with habitat quality, parasite pressure, and survival (Kaliński et al. 2014; Glądalski et al. 2015, 2018), while negative correlations between blood glucose concentration and other condition indices were found in adult waterbirds (e.g. Minias 2014). Consequently, we expected that high blood glucose concentrations would be associated with low physiological condition in the Black-headed Gull. This notion was supported by the negative correlation between haemoglobin and glucose concentrations $(r=-0.15, n=484, P<0.001)$ in our study populations. Correlations of body mass with blood haemoglobin and glucose concentrations were nonsignificant ( $P=0.95$ and $P=0.85$ for, respectively). For technical reasons (blood clotting or photometer malfunction), blood concentrations of haemoglobin and glucose were measured for 527 and 489 individuals (Table 1), respectively, i.e. $96.9 \%$ and $89.9 \%$ of all captured individuals, respectively. Since body mass and, possibly, some physiological traits are expected to be associated with body size (Green 2001), we controlled for wing length (as a proxy of overall body size) in all analyses of condition indices.

\section{Physiological stress}

To assess physiological stress, we performed leucocyte counts for a randomly selected subsample of 236 individuals (from seven to 21 individuals per colony). We collected a drop of blood from the ulnar vein of these birds during sampling for condition measurements. Blood was transferred to a slide and a smear of one cell layer was made. Smears were air dried and stored in darkness until analysis. Each smear was stained using the May-Grüunewald-Giemsa method and scanned at $1000 \times$ magnification under a light microscope. A random sample of 100 leucocytes from each smear was counted and classified into five cell types: heterophils, lymphocytes, eosinophils, basophils and monocytes.

Physiological stress was measured as a ratio of heterophils to lymphocytes (H/L ratio). In general, heterophils form the first line of immunological defence against a wide spectrum of pathogens and show high phagocytic activity in inflammatory lesions, while lymphocytes mediate antigenspecific responses (Harmon 1998). In a stressful environment, the number of lymphocytes in the peripheral blood decreases and the number of heterophils increases as they are released from bone marrow. This process of leucocyte trafficking is thought to be mediated through stress hormones and constitutes a basic adaptation of an organism to deal with an infection via injury (heterophils) rather than with a communicable disease (lymphocytes) (Johnstone et al. 2012).

Since $\mathrm{H} / \mathrm{L}$ ratios can reach extremely high values when the number of lymphocytes is low, we performed an outlier identification prior to the analyses. We identified two outliers $(\mathrm{H} / \mathrm{L}>4.95)$ using conservative criteria of $>4 \mathrm{SD}$. Both outliers were removed as they were likely to represent individuals under acute stress, resulting in the final sample size of 234 individuals (Table 1). After removing outliers, the $\mathrm{H} / \mathrm{L}$ ratio distribution remained right skewed (skewness $=1.37$ ) and was, thus, log transformed to improve normality. The repeatability of the $\mathrm{H} / \mathrm{L}$ ratio was relatively high $(R=0.81, P<0.001)$, as assessed through independent measurements of the same smears prepared for 25 individuals captured in previous seasons (Indykiewicz et al. 2019b). Although leucocyte profiles (and possibly some other physiological traits, e.g. blood glucose concentration) can change 
over relatively short time scales (Cīrule et al. 2012), most studies have shown that the $\mathrm{H} / \mathrm{L}$ ratio is relatively stable within the first hour following bird capture (Davis 2005; Buehler et al. 2008; D'Amico et al. 2017). Following these findings, most of the gulls in our study were sampled for blood within an hour from the moment of capture, but to exclude any bias we also controlled for sampling time (time interval between bird capture and blood sampling) in all the analyses. Correlations of $\mathrm{H} / \mathrm{L}$ ratio with all three condition indices were non-significant (all $P>0.4$ ).

\section{Statistical analyses}

We used general linear models (GLMs) to assess relationships of hood size with condition and physiological stress of Black-headed Gulls. Since hood size correlated positively with overall body size, as measured by wing length $(r=0.27$, $n=542, P<0.001)$, we also extracted residuals from a linear regression of hood size against wing length to obtain hood size estimates independent of body size (henceforth referred to as 'residual hood size'). Wing length could not be measured for two individuals with broken outermost primaries and, thus, residual hood size was calculated for 542 gulls. In order to examine the robustness of our results, we used two redundant modelling approaches, where either hood size or residual hood size were entered as predictors of condition or physiological stress. Condition indices (blood haemoglobin concentration, blood glucose concentration, and body mass) and $\mathrm{H} / \mathrm{L}$ ratio were entered as response variables in separate models. Hood size (or residual hood size), wing length, capture date, hour (time of day at sampling), and sampling time (time interval between bird capture and blood sampling) were entered as covariates, while sex was included as a fixed factor. To test whether associations between hood size with condition and physiological stress can be explained by the non-random distribution of individuals among the colonies, we also ran the same models as outlined above but with colony identity included as an additional fixed factor. Finally, we used GLMs to test for between-sex variation and intra-seasonal changes in hood size (sex and capture date included as a fixed factor and a covariate, respectively). To obtain more parsimonious reduced models, we removed nonsignificant $(P>0.05)$ predictors from the initial full models. Correlations between mean hood size and mean condition or physiological stress estimates across the colonies were tested with Pearson's correlation coefficient. All models were run using the lme4 package (Bates et al. 2015) developed for the R statistical environment (R Development Core Team 2013). We used the car package (Fox and Weisberg 2011) to obtain Wald $\chi^{2}(W)$ statistics and infer statistical significance $(P$-values) for all independent variables.

\section{Results}

Hood size was identified as a significant predictor of blood haemoglobin concentration and $\mathrm{H} / \mathrm{L}$ ratio in the Blackheaded Gull (Table 2). Gulls with larger hoods had higher haemoglobin concentrations and lower H/L ratios (Fig. 3), which is consistent with higher condition and lower physiological stress. Similar patterns were found after adjusting hood size for differences in overall body size (residual hood size; Electronic Supplementary Material, Table S1; Fig. 3). All these relationships were similar for males and females, as indicated by non-significant sex-hood size interactions (Table 2, S1). We found no relationships of hood size (or residual hood size) with body mass and blood glucose concentration (Table S2, S3).

We found large differences in the mean hood size (and residual hood size) between the colonies $(P<0.001)$.

Table 2 Models assessing relationships of hood size with blood haemoglobin concentration $(A)$ and heterophil/lymphocyte $(H / L)$ ratio $(B)$ in the Black-headed Gull

\begin{tabular}{|c|c|c|c|}
\hline Predictors & $\begin{array}{l}\text { Estimate } \\
(\text { mean } \pm S E)\end{array}$ & $W$ & $p$ \\
\hline \multicolumn{4}{|c|}{ Full model (blood haemoglobin concentration) (A) } \\
\hline Hood size $^{\mathrm{a}}$ & $0.48 \pm 0.14$ & 13.3 & $<0.001$ \\
\hline Sex & $11.2 \pm 14.7$ & 1.42 & 0.23 \\
\hline Sex $\times$ hood size & $-0.18 \pm 0.20$ & 0.84 & 0.36 \\
\hline Wing length & $0.08 \pm 0.09$ & 0.72 & 0.40 \\
\hline Date $^{\mathrm{a}}$ & $-0.14 \pm 0.05$ & 8.47 & 0.004 \\
\hline Hour $^{\mathrm{a}}$ & $-0.69 \pm 0.28$ & 5.86 & 0.016 \\
\hline Sampling time ${ }^{\mathrm{a}}$ & $0.07 \pm 0.02$ & 17.5 & $<0.001$ \\
\hline \multicolumn{4}{|c|}{ Reduced model (blood haemoglobin concentration) } \\
\hline Hood size $\mathrm{a}^{\mathrm{a}}$ & $0.41 \pm 0.10$ & 15.4 & $<0.001$ \\
\hline Date $^{\mathrm{a}}$ & $-0.14 \pm 0.05$ & 8.22 & 0.004 \\
\hline Hour $^{\mathrm{a}}$ & $-0.66 \pm 0.28$ & 5.42 & 0.020 \\
\hline Sampling time ${ }^{\mathrm{a}}$ & $0.08 \pm 0.02$ & 18.8 & $<0.001$ \\
\hline \multicolumn{4}{|c|}{ Full model (H/L ratio) (B) } \\
\hline Hood size ${ }^{\mathrm{a}}$ & $-0.0063 \pm 0.0019$ & 11.0 & $<0.001$ \\
\hline Sex & $-0.24 \pm 0.19$ & 0.00 & 0.98 \\
\hline Sex $\times$ hood size & $0.0034 \pm 0.0026$ & 1.66 & 0.20 \\
\hline Wing length & $-0.0002 \pm 0.0012$ & 0.04 & 0.85 \\
\hline Date $^{a}$ & $-0.0012 \pm 0.0006$ & 4.05 & 0.044 \\
\hline Hour & $-0.0051 \pm 0.0035$ & 2.07 & 0.15 \\
\hline Sampling time $^{\mathrm{a}}$ & $0.0011 \pm 0.0002$ & 18.4 & $<0.001$ \\
\hline \multicolumn{4}{|c|}{ Reduced model (H/L ratio) } \\
\hline Hood size $\mathrm{a}^{\mathrm{a}}$ & $-0.0048 \pm 0.0014$ & 12.6 & $<0.001$ \\
\hline Date $^{\mathrm{a}}$ & $-0.0014 \pm 0.0006$ & 5.48 & 0.019 \\
\hline Sampling time ${ }^{\mathrm{a}}$ & $0.0012 \pm 0.0002$ & 23.4 & $<0.001$ \\
\hline
\end{tabular}

Sample sizes were 527 and 234 individuals for blood haemoglobin concentration and $\mathrm{H} / \mathrm{L}$ ratio, respectively

${ }^{\text {a }}$ Significant predictors 

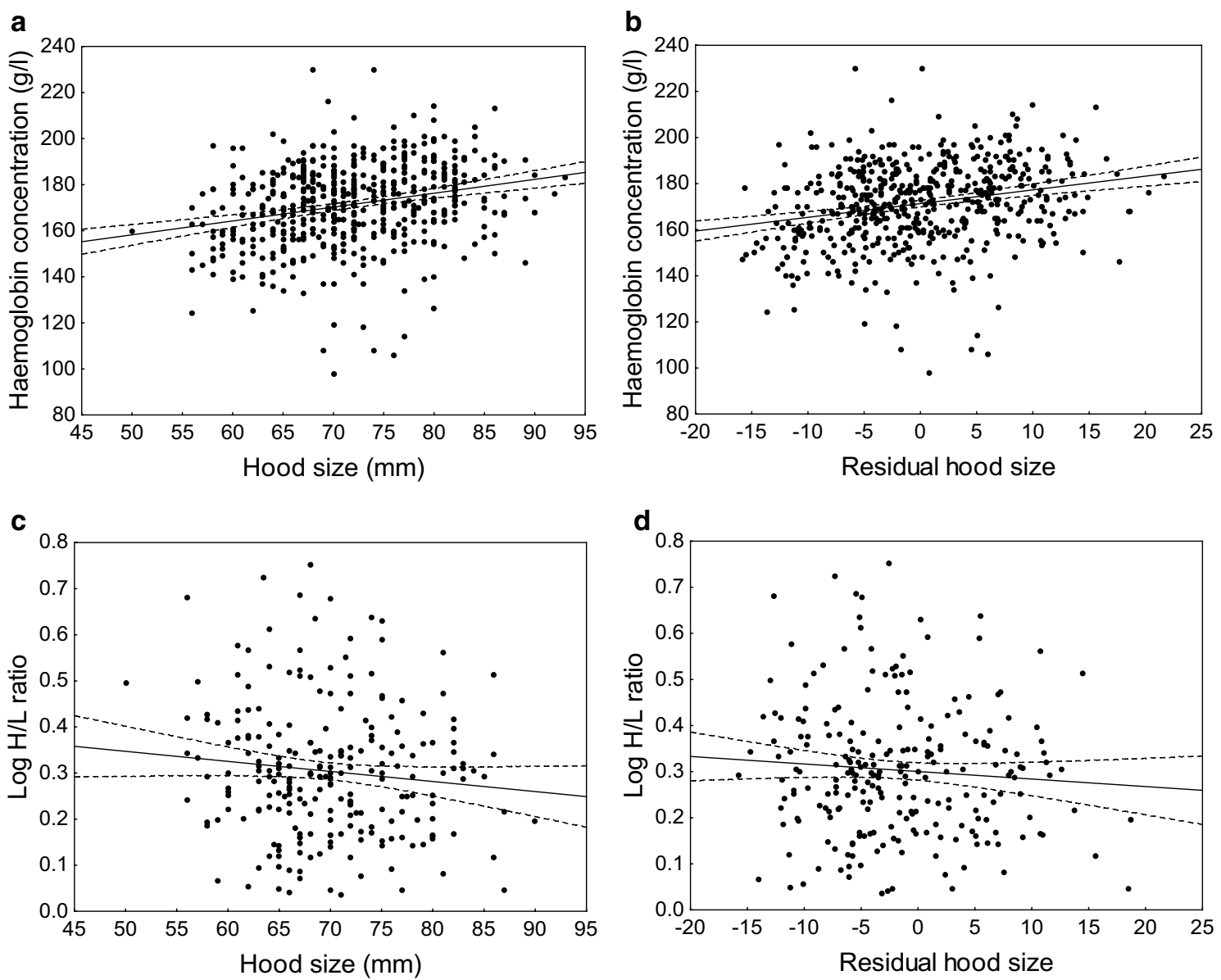

Fig. 3 Relationships of hood size and residual hood size (hood size-wing length residuals) with blood haemoglobin concentration (a, b) and heterophil/lymphocyte ratio (c, d) in the Black-headed Gull. Linear regression lines with 95\% confidence intervals are shown

Similarly, all condition indices showed significant intercolony variation (all $P<0.05$ ). After controlling for the effect of the colony, the relationship between hood size and blood haemoglobin concentration was no longer significant (Tables S4, S5). However, we found a significant positive correlation of mean hood size with mean blood haemoglobin concentrations across the colonies $(r=0.54$, $n=16, P=0.032$ for hood size; $r=0.52, n=16, P=0.039$ for residual hood size; Fig. 4). The relationship between hood size and H/L ratio was still significant after controlling for between-colony variation (Tables S4, S5), but no significant correlation was found between mean hood size and mean $\mathrm{H} / \mathrm{L}$ ratio across the colonies $(r=0.25$, $n=16, P=0.35$ for hood size; $r=0.24, n=16, P=0.36$ for residual hood size). No significant correlation was found between mean hood size and mean body mass or mean blood glucose concentration across the colonies (all $P>0.05)$.
Hood size differed significantly between the sexes ( $W=13.26, d f=1, P<0.001)$, but this difference was attributed to large variation in the overall structural size between males and females, as no significant differences were found for residual hood size $(W=0.00, d f=1$, $P=0.99)$. No between-sex differences were found for blood haemoglobin or glucose concentrations, or for $\mathrm{H} / \mathrm{L}$ ratio (Tables 2, S1-S3). Blood haemoglobin concentration and body mass decreased with date of sampling (Tables 2 , S1-S3) and a similar trend was observed for blood glucose concentration, although the latter was non-significant (Table S2-S3). H/L ratio also decreased with date of sampling (Tables 2, S1), suggesting that early breeding birds, despite being in better condition, are subject to higher physiological stress. We found no relationship between hood and residual hood size with sampling (capture) date (all $P>0.1$ ). 

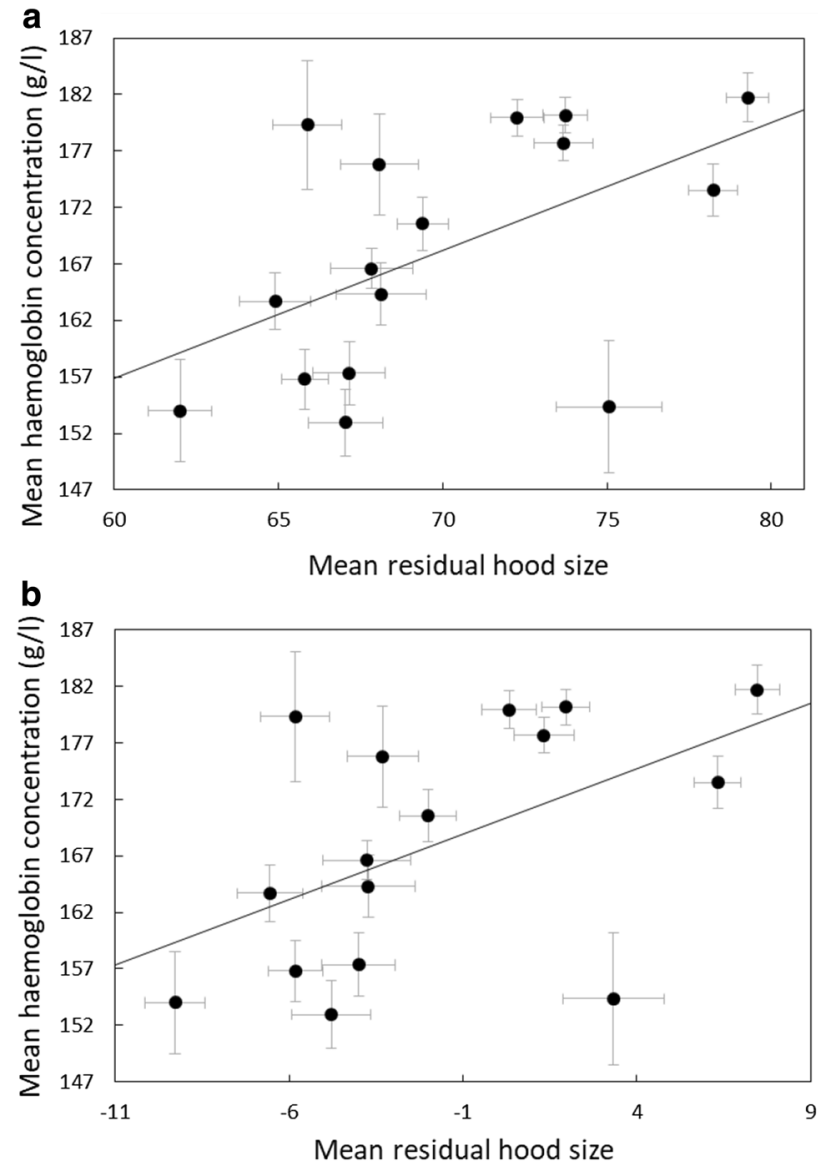

Fig. 4 Relationships of mean ( \pm SE) hood size (a) and residual hood size (b) (hood size-wing length residuals) with mean $( \pm$ SE) blood haemoglobin concentration across 16 colonies of the Black-headed Gull. Lines are Pearson correlations

\section{Discussion}

Our study provides correlative evidence for a positive association between the size of a melanin-based ornament (brown hood) and condition in the Black-headed Gull. At the same time, there was a negative relationship between hood size and the level of physiological stress, as assessed by leucocyte profiles ( $\mathrm{H} / \mathrm{L}$ ratio). These results indicate that hood size has the potential to be a reliable indicator of condition in the Black-headed Gull.

Hood size in the Black-headed Gull correlated positively with blood haemoglobin concentration, although we found no evidence for a relationship between hood size and blood glucose concentration or body mass. This indicates that hood size may reflect some specific components of physiological condition in our study species. Haemoglobin concentration is a basic measure of the oxygen-carrying capacity of blood, which has been demonstrated to reflect diet quality and to correlate with general condition in a wide spectrum of bird species (reviewed in Minias 2015). Blood haemoglobin concentration was also negatively associated with infestation rates of different parasites, including hematozoans (Haemoproteus, Leucocytozooan, Plasmodium, and Trypanosoma) (Sergent et al. 2004; Mandal et al. 2008; Krams et al. 2013), gastrointestinal helminths (Mazur et al. 2007), ticks (Norte et al. 2013), and parasitic arthropods (e.g. Fessl et al. 2006; Słomczyński et al. 2006). Thus, it seems likely that the positive relationship between hood size and blood haemoglobin concentration can be mediated by parasitic infection, which is a common mechanism of honest ornamental expression in birds and other animals [according to the parasite hypothesis of Hamilton and Zuk (1982)]. This hypothesis is further supported by the negative relationship between hood size and $\mathrm{H} / \mathrm{L}$ ratio in our study. Although leucocyte profiles respond to various environmental stressors via androgen-mediated cell trafficking (Johnstone et al. 2012), high H/L ratios (heterophilia) can also be caused by inflammation resulting from parasitic or bacterial infection (Davis et al. 2004; Lobato et al. 2005). Negative correlations between $\mathrm{H} / \mathrm{L}$ ratios and the expression of carotenoid-based ornaments have been reported for several avian species (e.g. Pérez-Rodríguez and Viñuela 2008; Kelly et al. 2012; but see Maney et al. 2008), although we are aware of no previous study reporting a similar correlation for melanin-based plumage ornaments [but see Svobodová et al. (2013) for a positive correlation between the size of a melanin-based ornament and $\mathrm{H} / \mathrm{L}$ ratio in the Grey Partridge Perdix perdix]. It must be, however, stressed that although the negative association between hood size (or residual hood size) and $\mathrm{H} / \mathrm{L}$ ratio in the Blackheaded Gull appeared to be statistically significant, the slopes of these relationships were shallow (Tables 2, S1; Fig. 3c, d) and data dispersion was high. Thus, we cannot exclude the possibility that the biological significance of these associations may be limited, and we suggest that these results should be treated with caution.

Relationships of hood size with blood haemoglobin concentration and $\mathrm{H} / \mathrm{L}$ ratios were apparent in both sexes, suggesting that the hood may be an honest signal of individual quality in males and females. This pattern is consistent with theoretical expectations, since the Black-headed Gull is a sexually monochromatic species in which mutual mate choice can occur (Amundsen 2000). On the other hand, the relationship of hood size with blood haemoglobin concentration (but not $\mathrm{H} / \mathrm{L}$ ratio) could be primarily attributed to the parallel variation of these traits among the colonies (birds in certain colonies had larger hoods and higher haemoglobin concentrations than birds from other colonies). It seems unlikely that this pattern is directly driven by environmental variation between the colonies, as hoods are usually developed prior to the arrival of birds at their breeding grounds and, hence, possibly under very different environmental conditions than those experienced later in reproductive colonies. Rather, we favour the despotic distribution hypothesis, where 
colonies substantially vary in attractiveness (in terms of food availability, nesting sites, predators, etc.) and birds settle in colonies non-randomly with respect to their individual quality (Fretwell 1972; Brown et al. 1990). Consequently, we expect birds with larger hoods to settle in more attractive colonies, which leads to an improvement of their condition during the reproductive period. Our ringing data indicate that there is low breeding site fidelity within our metapopulation of Black-headed Gulls and that the birds often change breeding colonies between seasons. This suggests that colony choice may be determined by the physical condition of birds during the settlement period. When an individual is in good condition upon arrival it can compete for a nesting site in an attractive colony, but when it arrives at the breeding grounds in poor condition, it may have a higher probability of being relegated to a colony of inferior attractiveness in a given year. It has to be stressed, however, that the inter-colony character of an association between hood size and haemoglobin concentration does not undermine the potential signalling role of the hood, but does indicate that birds are non-randomly distributed in space with respect to both traits. So far, this kind of despotic distribution has only been reported for a few colonial bird species. For example, young Greater Flamingos Phoenicopterus ruber were found to prospect in a high-quality colony early in the season, but later settled in a poor-quality colony, probably because of age-related behavioural dominance (Rendón et al. 2001). Poor-quality Yellow-legged Gulls Larus michahellis were also prevented from settling in high-quality habitat patches by locally breeding birds (Oro 2008), while first-breeding Lesser Kestrels Falco naumanni recruited in colonies smaller than those in which they first tried to settle because of agonistic interactions that decreased with colony size (Serrano and Tella 2006).

As far as we are aware, our study is one of the first to support the possibility that melanin-based ornaments can be used as honest signals of individual quality in the gull family, Laridae. A brownish or blackish hood is a common type of a putative ornament in gulls, and it occurs in nearly one-third of all extant gull species [ 16 out of 52 species recognized by Winkler et al. (2015)] from several genera (Chroicocephalus, Creagrus, Hydrocoloeus, Ichthyaetus, Larus, Leucocephalus, Saunderlarus, and Xema). The ubiquity of melanin-based hood coloration in different gull lineages suggests that this plumage character may play an important role in mate selection and intra-sexual competition. Thus, is seems surprising that there are virtually no empirical data on the behavioural functions of gull hoods. Some research has been conducted on the black (melaninbased) wingtip of gulls, but the conclusions of this was equivocal. In the Common Gull Larus canus, absolute and relative (to white patch area) size of the black wingtip was negatively associated with survival and positively with feather abrasion, suggesting that it may signal poor individual quality (Sepp et al. 2017). In contrast, the symmetry of black wingtips in the Black-legged Kittiwake Rissa tridactyla positively correlated with clutch size and intensity of carotenoid-based integument coloration (Leclaire et al. 2013). Our previous research provides support for assortative mating by both hood size and black wingtip size in the Black-headed Gull (Indykiewicz et al. 2017), although neither of these characters were inter-correlated within each sex (P. I., unpublished data). Thus, we suggest that hoods and wingtips can possibly act as partially independent ornaments in gulls.

Previous research on the role of ornaments in mate selection by gulls was focused almost exclusively on the carotenoid-based coloration of integuments. For example, the intensity of the carotenoid-based coloration of the bill, gape and eye-ring correlated with condition (size-corrected body mass) in male Great Black-backed Gulls Larus marinus, while in females these were positively associated with egg volume and clutch size (Kristiansen et al. 2006). Similarly, carotenoid-based coloration of the gape, tongue, eye-ring, and bill was also found to signal phenotypic (body condition) and genetic (heterozygosity) quality, as well as reproductive success, in the Black-legged Kittiwake (Leclaire et al. 2011; Doutrelant et al. 2013). These data provide strong support for an adaptive function of carotenoid-based ornaments in gulls and suggest that the same may apply to the Black-headed Gull, which shows intensive red coloration of the bill, gape and legs during the reproductive season. This raises the question as to whether, and how, different plumage and integument ornaments, especially those based on different pigmentation, are functionally integrated in gulls? It is likely that, as in other bird species, independent components of ornaments can evolve into a composite sexual trait that reliably reflects condition across a wide array of environments (Badyaev et al. 2001). There is also increasing evidence that different ornaments (carotenoid versus melanin based) can signal similar aspects of individual quality under different environmental conditions, as natural and sexual selection can lead to geographical divergence in mate selection mechanisms (Dunn et al. 2008, 2010).

In conclusion, our study adds to the existing body of evidence for the honest signalling of melanin-based ornaments in birds, and is one of the first to support this hypothesis in gulls. Our results also suggest that the distribution of gulls among breeding colonies may be despotic, thus producing large between-colony variation in the level of ornament expression and phenotypic quality of individuals. It remains to be tested whether different melanin-based plumage ornaments in gulls are developmentally and functionally integrated with each other and with carotenoid-based integument coloration, and whether physiological condition is mechanistically linked to the production of hood ornaments. 
Acknowledgements We thank Julita Gerke and Joanna Kudełka from the UTP Student Zoological Group in Bydgoszcz for conducting the leucocyte counts. We also thank A. Górski, P. Knozowski, P. Podlaszczuk, and A. M. Stawicka for help with the fieldwork. We are grateful to Jana Svobodová and one anonymous reviewer for constructive comments on the earlier draft of the manuscript. The study was performed with the permission of the Local Bioethical Commission for Animal Welfare in Łódź and the Regional Environmental Protection Directorates in Bydgoszcz, Łódź, Kraków, Poznań, and Olsztyn (Poland). The data used in this study are available from the corresponding authors upon request.

Open Access This article is distributed under the terms of the Creative Commons Attribution 4.0 International License (http://creativeco mmons.org/licenses/by/4.0/), which permits unrestricted use, distribution, and reproduction in any medium, provided you give appropriate credit to the original author(s) and the source, provide a link to the Creative Commons license, and indicate if changes were made.

\section{References}

Allainé D, Lebreton J-D (1990) The influence of age and sex on wingtip pattern in adult Black-headed Gulls Larus ridibundus. Ibis 132:560-567

Alonso-Alvarez C, Pérez-Rodríguez L, Mateo R, Chastel O, Vinuela $\mathrm{J}$ (2008) The oxidation handicap hypothesis and the carotenoid allocation trade-off. J Evol Biol 21:1789-1797

Amundsen T (2000) Why are female birds ornamented? Trends Ecol Evol 15:149-155

Andersson M (1994) Sexual selection. Princeton University Press, Princeton

Badyaev AV, Hill GE, Dunn PO, Glen JC (2001) Plumage color as a composite trait: developmental and functional integration of sexual ornamentation. Am Nat 158:221-235

Bates D, Maechler M, Bolker B, Walker S (2015) Fitting linear mixedeffects models using lme4. J Stat Soft 67:1-48

Bókony V, Garamszegi LZ, Hirschenhauser K, Liker A (2008) Testosterone and melanin-based black plumage coloration: a comparative study. Behav Ecol Sociobiol 62:1229-1238

Brown ME (1996) Assessing body condition in birds. Curr Ornithol 13:67-135

Brown CR, Stutchbury BJ, Walsh PD (1990) Choice of colony size in birds. Trends Ecol Evol 5:398-403

Buchanan KL, Evans MR, Goldsmith AR (2003) Testosterone, dominance signalling and immunosuppression in the House Sparrow, Passer domesticus. Behav Ecol Sociobiol 55:50-59

Buehler DM, Bhola N, Barjaktarov D, Goymann W, Schwabl I, Tieleman BI, Piersma T (2008) Constitutive immune function responds more slowly to handling stress than corticosterone in a shorebird. Physiol Biochem Zool 81:673-681

Cīrule D, Krama T, Vrublevska J, Rantala MJ, Krams I (2012) A rapid effect of handling on counts of white blood cells in a wintering passerine bird: a more practical measure of stress? J Ornithol 153:161-166

Corbel H, Geiger S, Groscolas R (2010) Preparing to fledge: the adrenocortical and metabolic responses to stress in King Penguin chicks. Funct Ecol 24:82-92

D’Amico VL, Palacios MG, Baker AJ, González PM, Madrid E, Bertellotti M (2017) Physiologic parameters and their responses to handling stress in a Neotropical migratory shorebird during the nonbreeding season. J Wildl Dis 53:437-446
Dauwe T, Eens M (2008) Melanin-and carotenoid-dependent signals of Great Tits (Parus major) relate differently to metal pollution. Naturwissenschaften 95:969-973

Davis AK (2005) Effects of handling time and repeated sampling on avian white blood cell counts. J Field Ornithol 76:334-338

Davis AK, Cook KC, Altizer S (2004) Leukocyte profiles in wild House Finches with and without mycoplasmal conjunctivitis, a recently emerged bacterial disease. EcoHealth 1:362-373

Doutrelant C, Grégoire A, Gomez D, Staszewski V, Arnoux E, Tveraa T, Boulinier T (2013) Colouration in Atlantic Puffins and Blacklegged kittiwakes: monochromatism and links to body condition in both sexes. J Avian Biol 44:451-460

Ducrest AL, Keller L, Roulin A (2008) Pleiotropy in the melanocortin system, coloration and behavioural syndromes. Trends Ecol Evol 23:502-510

Dunn PO, Whittingham LA, Freeman-Gallant CR, DeCoste J (2008) Geographic variation in the function of ornaments in the Common Yellowthroat Geothlypis trichas. J Avian Biol 39:66-72

Dunn PO, Garvin JC, Whittingham LA, Freeman-Gallant CR, Hasselquist D (2010) Carotenoid and melanin-based ornaments signal similar aspects of male quality in two populations of the Common Yellowthroat. Funct Ecol 24:149-158

Ferns PN, Hinsley SA (2004) Immaculate tits: head plumage pattern as an indicator of quality in birds. Anim Behav 67:261-272

Fessl B, Kleindorfer S, Tebbich S (2006) An experimental study on the effects of an introduced parasite in Darwin's finches. Biol Conserv 127:55-61

Fox J, Weisberg S (eds) (2011) An R companion to applied regression. Sage, Thousand Oaks

Fretwell SD (1972) Populations in seasonal environments. Princeton University Press, Princeton

Giraudeau M, Mateos-Gonzalez F, Cotín J, Pagani-Nuñez E, TornéNoguera A, Senar JC (2015) Metal exposure influences the melanin and carotenoid-based colorations in Great Tits. Sci Total Environ 532:512-516

Glądalski M, Skwarska J, Kaliński A, Bańbura M, Markowski M, Wawrzyniak J, Zieliński P, Bańbura J (2015) Patterns of year-toyear variation in haemoglobin and glucose concentrations in the blood of nestling Pied Flycatchers, Ficedula hypoleuca. J Ornithol 156:811-817

Glądalski M, Kaliński A, Wawrzyniak J, Bańbura M, Markowski M, Skwarska J, Bańbura J (2018) Physiological condition of nestling Great Tits Parus major in response to experimental reduction in nest micro-and macro-parasites. Conserv Physiol 6:coy062

Green AJ (2001) Mass/length residuals: measures of body condition or generators of spurious results? Ecology 82:1473-1483

Griffith SC, Parker TH, Olson VA (2006) Melanin-versus carotenoidbased sexual signals: is the difference really so black and red? Anim Behav 71:749-763

Guindre-Parker S, Love OP (2014) Revisiting the condition-dependence of melanin-based plumage. J Avian Biol 45:29-33

Hamilton WD, Zuk M (1982) Heritable true fitness and bright birds: a role for parasites? Science 218:384-387

Harmon BG (1998) Avian heterophils in inflammation and disease resistance. Poult Sci 77:972-977

Hill GE (1991) Plumage coloration is a sexually selected indicator of male quality. Nature 350:337-339

Hill GE, Inouye CY, Montgomerie R (2002) Dietary carotenoids predict plumage coloration in wild House Finches. Proc R Soc B 269:1119-1124

Indykiewicz P, Podlaszczuk P, Surmacki A, Kudelska K, Kosicki J, Kamiński M, Minias P (2017) Scale-of-choice effect in the assortative mating by multiple ornamental and non-ornamental characters in the Black-headed gull. Behav Ecol Sociobiol 71:183 
Indykiewicz P, Minias P, Kowalski J, Podlaszczuk P (2019a) Shortcomings of discriminant functions: a case study of sex identification in the black-headed gull. Ardeola 66:361-372

Indykiewicz P, Podlaszczuk P, Kamiński M, Włodarczyk R, Minias P (2019b) Central-periphery gradient of individual quality within a colony of Black-headed Gulls. Ibis. https://doi.org/10.1111/ibi12 689

Johnsen A, Delhey K, Andersson S, Kempenaers B (2003) Plumage colour in nestling Blue Tits: sexual dichromatism, condition dependence and genetic effects. Proc R Soc B 270:1263-1270

Johnstone CP, Reina RD, Lill A (2012) Interpreting indices of physiological stress in free-living vertebrates. J Comp Physiol B 182:861-879

Kaliński A, Bańbura M, Glądalski M, Markowski M, Skwarska J, Wawrzyniak J, Zieliński P, Cyżewska I, Bańbura J (2014) Landscape patterns of variation in blood glucose concentration of nestling Blue Tits (Cyanistes caeruleus). Landsc Ecol 29:1521-1530

Kelly RJ, Murphy TG, Tarvin KA, Burness G (2012) Carotenoid-based ornaments of female and male American Goldfinches (Spinus tristis) show sex-specific correlations with immune function and metabolic rate. Physiol Biochem Zool 85:348-363

Krams IA, Suraka V, Rantala MJ, Sepp T, Mierauskas P, Vrublevska J, Krama T (2013) Acute infection of avian malaria impairs concentration of haemoglobin and survival in juvenile altricial birds. J Zool 291:34-41

Kristiansen KO, Bustnes JO, Folstad I, Helberg M (2006) Carotenoid coloration in Great Black-backed Ggull Larus marinus reflects individual quality. J Avian Biol 37:6-12

Leclaire S, White J, Arnoux E, Faivre B, Vetter N, Hatch SA, Danchin É (2011) Integument coloration signals reproductive success, heterozygosity, and antioxidant levels in chick-rearing Black-legged Kittiwakes. Naturwissenschaften 98:773-782

Leclaire S, Blanchard P, White J, Hatch SA, Danchin É (2013) Symmetry of black wingtips is related to clutch size and integument coloration in Black-legged Kittiwakes (Rissa tridactyla). Auk 130:541-547

Lobato E, Moreno J, Merino S, Sanz JJ, Arriero E (2005) Haematological variables are good predictors of recruitment in nestling Pied Flycatchers (Ficedula hypoleuca). Ecoscience 12:27-34

Mandal M, Laha R, Sasmal NK (2008) First report of establishment of Trypanosoma evansi infection in Pigeon nestlings (Columba livia). J Parasitol 94:1428-1429

Maney DL, Davis AK, Goode CT, Reid A, Showalter C (2008) Carotenoid-based plumage coloration predicts leukocyte parameters during the breeding season in Northern Cardinals (Cardinalis cardinalis). Ethology 114:369-380

Mazur OE, Pronin NM, Tolochko LV (2007) Hematological and immunological properties of Herring Gull (Larus argentatus) nestlings experimentally infected with Diphyllobothrium dendriticum (Cestoda: Pseudophyllidae). Biol Bull 34:346-352

McGraw KJ (2007) Dietary mineral content influences melanin-based ornamental coloration. Behav Ecol 18:137-142

McGraw KJ (2008) An update on the honesty of melanin-based color signals in birds. Pigm Cell Melanoma Res 21:133-138

Minias P (2014) High glucose concentrations are associated with symptoms of mild anaemia in Whiskered Terns: consequences for assessing physiological quality in birds. J Ornithol 155:1067-1070

Minias P (2015) The use of haemoglobin concentrations to assess physiological condition in birds: a review. Conserv Physiol 3:cov007

Norte AC, Lobato DNC, Braga EM, Antonini Y, Lacorte G, Gonçalves M, Ramos JA (2013) Do ticks and Borrelia burgdorferi s.l. constitute a burden to birds? Parasitol Res 112:1903-1912

Oro D (2008) Living in a ghetto within a local population: an empirical example of an ideal despotic distribution. Ecology 89:838-846
Palomares LE, Arroyo BE, Marchamalo J, Sainz JJ, Voslamber B (1997) Sex- and age-related biometric variation of Black-headed Gulls Larus ridibundus in Western European populations. Bird Study 44:310-317

Pérez-Rodríguez L, Viñuela J (2008) Carotenoid-based bill and eye ring coloration as honest signals of condition: an experimental test in the Red-legged Partridge (Alectoris rufa). Naturwissenschaften 95:821-830

Poston JP, Hasselquist D, Stewart IR, Westneat DF (2005) Dietary amino acids influence plumage traits and immune responses of male House Sparrows, Passer domesticus, but not as expected. Anim Behav 70:1171-1181

Pryke SR, Rollins LA (2012) Mothers adjust offspring sex to match the quality of the rearing environment. Proc R Soc B 279:4051-4057

Pryke SR, Rollins LA, Griffith SC (2011) Context-dependent sex allocation: constraints on the expression and evolution of maternal effects. Evolution 65:2792-2799

R Development Core Team (2013) R: a language and environment for statistical computing version 341. R Foundation for Statistical Computing, Vienna. http://www.r-project.org/. Accessed 26 Oct 2013

Remage-Healey L, Romero ML (2001) Corticosterone and insulin interact to regulate glucose and triglyceride levels during stress in a bird. Am J Physiol Regul Integr Comp Physiol 281:R994-R1003

Rendón MA, Garrido A, Ramírez JM, Rendón-Martos M, Amat JA (2001) Despotic establishment of breeding colonies of Greater Flamingos, Phoenicopterus ruber, in southern Spain. Behav Ecol Sociobiol 50:55-60

Saks L, Ots I, Hõrak P (2003) Carotenoid-based plumage coloration of male Greenfinches reflects health and immunocompetence. Oecologia 134:301-307

Sepp T, Rattiste K, Saks L, Meitern R, Urvik J, Kaasik A, Hõrak P (2017) A small badge of longevity: opposing survival selection on the size of white and black wing markings. J Avian Biol 48:570-580

Sergent N, Rogers T, Cunningham M (2004) Influence of biological and ecological factors on hematological values in wild Little Penguins, Eudyptula minor. Comp Biochem Physiol A 138:333-339

Serrano D, Tella JL (2006) The role of despotism and heritability in determining settlement patterns in the colonial Lesser Kestrel. Am Nat 169:E53-E67

Słomczyński R, Kaliński A, Wawrzyniak J, Bańbura M, Skwarska J, Zieliński P, Bańbura J (2006) Effects of experimental reduction in nest micro-parasite and macro-parasite loads on nestling hemoglobin level in Blue Tits Parus caeruleus. Acta Oecol 30:223-227

Stettenheim PR (2000) The integumentary morphology of modern birds-an overview. Am Zool 40:461-477

Svobodová J, Gabrielová B, Synek P, Marsik P, Vaněk T, Albrecht T, Vinkler M (2013) The health signalling of ornamental traits in the Grey Partridge (Perdix perdix). J Ornithol 154:717-725

Svobodová J, Bauerová P, Eliáš J, Velová H, Vinkler M, Albrecht T (2018) Sperm variation in Great Tit males (Parus major) is linked to a haematological health-related trait, but not ornamentation. $\mathrm{J}$ Ornithol 159:815-822

Winkler DW, Billerman SM, Lovette IJ (2015) Bird families of the world: an invitation to the spectacular diversity of birds. Lynx, Barcelona

Publisher's Note Springer Nature remains neutral with regard to jurisdictional claims in published maps and institutional affiliations. 